\title{
Two new Oculatella (Oculatellaceae, Cyanobacteria) species in soil crusts from tropical semi-arid uplands of México
}

\author{
Itzel BeCERRA-AbSalón ${ }^{1 *}$, Jeffrey R. Johansen ${ }^{2,3}$, Karina OSORIo-SAntos ${ }^{1} \&$ \\ Gustavo MonTEJAnO ${ }^{1}$
}

\author{
${ }^{1}$ Departamento de Biología Comparada, Universidad Nacional Autónoma de México (UNAM), Colonia Coyoacán, \\ Código Postal 04451070474, P.O. Box 70-474, Ciudad de México, México; *Corresponding author; phone: \\ 52-5556224837; email: iba@ciencias.unam.mx \\ ${ }^{2}$ Department of Biology, John Carroll University, University Heights, Ohio 44118 USA \\ ${ }^{3}$ Department of Botany, Faculty of Science, University of South Bohemia, Branišovská 31, CZ-370 05 České \\ Budějovice, Czech Republic
}

\begin{abstract}
Two isolates of Oculatella from biological soil crusts in the arid and semi-arid tropical upland region of México were characterized using a polyphasic approach which included morphology, ecology, 16S rRNA and 16S-23S ITS phylogenetic analysis, percent identity of 16S rRNA gene sequence, percent dissimilarity of 16S-23S ITS sequence, and secondary structure of conserved ITS domains. The two species shared the generic synapomorphy of a reddish granule at the tip of mature apical cells, and possessed a single ribosomal operon with both tRNA genes (tRNA ${ }^{\mathrm{Ile}}$ and tRNA ${ }^{\mathrm{Ala}}$ ) based upon our analysis and the analysis of the other species in the genus. After characterization, the strains were compared with 10 previously described and similarly characterized species in the genus, and based upon the evidence obtained, the strains were described as two new species, $O$. dilatativagina and $O$. leona. O. dilatativagina has an extensively widened sheath, and thus is morphologically separated from all other taxa described thus far. $O$. leona is morphologically highly similar to soil species found in North and South America, and should be considered a cryptic species among these taxa. The recently developed criterion for species recognition using percent dissimilarity among ITS gene sequences in orthologous ribosomal operons was found to be effective in separating cryptic species of Oculatella, and has consistently been useful and sufficient for separation of closely related species in other cyanobacterial genera.
\end{abstract}

Key words: biological soil crust, cryptic species, cyanobacteria, dissimilarity, Oculatellaceae, semi-arid tropical, Synechococcales, 16S rRNA, 16S-23S ITS

\section{INTRODUCTION}

The genus Oculatella was separated from Leptolyngbya based on morphological and molecular characteristics (ZAMмIT et al. 2012). The genus is consistently and easily characterized, being morphologically distinguished from all other filamentous cyanobacteria by the presence of a reddish rhodopsin inclusion at the tip of mature apical cells (AlBERTANo et al. 2000).

The type species is O. subterranea Zammit, Billi et Albertano, morphologically and ecologically characterized by reddish trichomes and hypogeal habitat requirements (ZAMMIT et al. 2012). After it was taxonomically recognized, nine additional species were described from different environments. It currently appears that this genus occurs widely distributed in several habitats: $O$. cataractarum Bohunická et J.R.Johans., from a waterfall in semi-arid shrub-steppe, O. hafneriensis Kováčik et
J.R.Johans., from suspended benthos of a temperate lake in Austria, O. neakameniensis Kováčik et J.R.Johans., from semi-arid volcanic soil of the island of Nea Kameni, Greece, O. mojaviensis Pietrasiak et J.R.Johans., from dolomitic soils in hot desert of North America, O. coburnii Pietrasiak et J.R.Johans., from granitic soils of North America, O. atacamensis Osorio-Santos et J.R.Johans., from soils and diaphanous rocks in the Atacama Desert of Chile, O. kauaiensis Miscoe et J.R.Johans., from a damp cave wall in the tropical island biome of the north shore of the island of Kauai, Hawaii, O. ucranica Vynogr. et Mikhailyuk, from crust on surface of coquina, clay and chalk outcrops and O. kazantipica Vynogr. et Mikhailyuk, from crust on coquina beach at seaside, the last two occurring in the coast of the sea of Azou (OsORIO-SANTOS et al. 2014; VinOGRADOVA et al. 2017).

All these species were characterized and delimited based on combined analysis of differences in morphology, 
in sequences of the $16 \mathrm{~S}$ rRNA gene, in secondary structure of conserved domains of the $16 \mathrm{~S}-23 \mathrm{~S}$ ITS region, and in $\mathrm{p}$-distances between sequences of the $16 \mathrm{~S}-23 \mathrm{~S}$ ITS region (ZAMMIT et al. 2012; OsORIO-SANTOS et al. 2014; VinOGRADOVA et al. 2017).

Some species had clear morphological and molecular separation from all other species, such as $O$. subterranea, while others were morphologically so similar that they were considered cryptic species. Ecological differences were considered diagnostic for some, particularly those from aquatic habitats $(O$. hafneriensis, O. cataractarum) or tropical habitat $(O$. kauaiensis). However, the numerous terrestrial species were delimited and separated only by their differences in ITS secondary structures and p-distance analysis of the 16S-23S ITS region (OsORIO-SANTOS et al. 2014).

We observed two strains of filamentous cyanobacteria that were isolated from samples from two locations in the central region of México: Actopan in Hidalgo state and Atexcac in Puebla state. Morphologically they were identified as Oculatella by the presence of the typical granule of rhodopsin in mature apical cells, and later phylogenetic analysis confirmed their placement in the genus. Our strains have morphological differences between them that differentiate them, and the comparative analyses with the described morphological, morphometric, ITS secondary structure, phylogeny based on the ITS regions, and p-distance based on the ITS alignment, indicate that they are two new species, which are described in this work as Oculatella dilatativagina sp. nov. and Oculatella leona sp. nov.

\section{Material and Methods}

Sample collection and cultures. Oculatella filaments were found inhabiting soil crusts of tropical semi-desert uplands in Central México in two localities: one near to Actopan, Hidalgo state within the Mezquital Valley, and the other around the crater lake of San Luis Atexcac (L.A.), Puebla state. These localities constitute the southern end of the Chihuahuan Desert and the two sites are separated by a mountain range of basaltic volcanic flows.

We collected surface samples of biocrust in sterile plastic petri dishes $15 \mathrm{~cm}$ in diameter, which were then stored in darkness inside envelopes until processing. The samples were dried for preservation and deposited in the collection of Biological Crusts of the Phycological Herbarium of Science Faculty (FCME) from Universidad Nacional Autónoma de México (UNAM). A subsample of each soil sample was broken up by grinding in a mortar with a pestle, and then dried crushed soil was applied directly to agar plates containing BG11 medium (Allen 1968). The Oculatella filaments were isolated from the first inoculated dishes and seeded in petri dishes with BG 11 medium. At the end two unicyanobacterial strains were obtained, UAM 687 and UAM 710. The cultures were grown in a culture room at $28{ }^{\circ} \mathrm{C}$ with continuous light of 20-50 $\mu \mathrm{E}$ (for details see BECERRA-ABSALón et al. 2018). Strains were deposited in the UAM Culture Collection, Universidad Autónoma de Madrid, Spain and the UNAM Culture Collection, Universidad Nacional Autónoma de México. Afterwards, these two strains were grown in liquid BG11 medium on a motion plate, to obtain sufficient biomass for genomic DNA extraction.

Morphological characterization. Morphological variability was studied in live culture material (Oculatella strains UAM 687 and UAM 710). Morphological and morphometric features were characterized, including: sheath morphology, filament and trichome width, trichome morphology, coloration, cell and apical cell length, presence or absence of granules, and presence or absence of false branching. The observations were carried out on an Olympus BX 51 microscope equipped with differential interference contrast (DIC) optics and a DP 12 digital camera, or an Olympus CX 41 microscope and DP 20 digital camera. We used Sigma Scan Pro to obtain accurate measurements from photomicrographs. The characteristics of our strains were compared to Oculatella species in other taxonomic treatments, e.g. KomáreK \& ANagnostidis (2005), Zammit et al. (2012), OsORIO-SANTOS et al. (2014), and VinOGRAdOva et al. (2017).

Molecular characterization. The partial 16S rRNA gene with full $16 \mathrm{~S}-23 \mathrm{~S}$ ITS region was amplified by polymerase chain reaction (PCR) using primer 27 Forward (WILMOTTE et al. 1993) and primer 23S Reverse (LEPÉRE et al. 2000), for details of extraction and amplification see BECERRA-ABSALÓN et al. (2018). The amplified products were run in a Perkin Elmer Gene Amp PCR System 2400 Thermocycler, using the PCR cycle described by GKelis et al. (2005). PCR products were visualized on a $1 \%$ agarose gel and the amplification products were purified with Wizard $®$ SV Gel and PCR CleanUp System, Promega. The purification products were cloned onto the pGEM ${ }^{\circledR}-\mathrm{T}$ Easy Vector plasmid of the pGEM ${ }^{\circledR}-\mathrm{T}$ Easy Vector System I, Promega. The clones were isolated using Wizard $\AA$ Plus SV Minipreps DNA purification System, Promega. Plasmids containing inserts were submitted for bidirectional sequencing using plasmid primers T7 and SP6, with primer 684 Forward as an internal primer (MATEO et al. 2011) to the Centro Nacional de Investigación Oncológica (CNIO) in Madrid. Fragments were assembled using the software PhyDE-1 v0.9971 (MüLLER et al. 2010).

Phylogenetic analysis. The sequences obtained were combined with an internal reference set of synechococcalean taxa representing the families Oculatellaceae, Leptolyngbyaceae, Prochlorotrichaceae, Trichocoleusaceae, and Pseudanabaenaceae (MAI et al. 2018), with five Synechococcus-like strains and three Gloeobacter strains used as outgroup taxa. The taxa used in the 16S rRNA gene phylogenetic analyses included a total of 270 sequences. The multiple-sequence alignment was performed using ClustalW (Thompson et al. 1994) and the alignment was later visually checked and corrected for secondary structure preservation. Percent identity among strains based on the 16S rRNA gene sequence alignment and percent dissimilarity based on the 16S-23S ITS sequence alignment were derived from $\mathrm{p}$-distance as obtained with the SHOWDIST command (distance $=\mathrm{p}$ ) in PAUP 4.0 beta version 10 .

Bayesian inference (BA) and maximum likelihood (ML) analyses were performed using partial 16S rRNA gene sequences containing a maximum of 1448 characters including nucleotides and indels. Bayesian inference was conducted with MrBayes XSEDE V3.2.6 (RonQuIST et al. 2012) through the CIPRES Science Gateway, applying the GTR $+\mathrm{G}+\mathrm{I}$ model of nucleotide substitutions. A total of 50 million generations were run. The BI analysis had an estimated sample size (ESS) exceeding 275 for all parameters (average ESS ranging $809-28,200$ ), well above the average of 200 typically accepted 
as sufficient by phylogeneticists (DRUMMOND et al. 2006). The final average standard deviation of split frequencies was 0.011. The potential scale reduction factor (PSRF) value for all the estimated parameters in the Bayesian analysis was 1.00 , indicating that convergence of the MCMC chains was statistically achieved (GELMAN \& RUBIN 1992). The ML analysis with rapid bootstrapping was conducted using RAxML-HPC v.8 on XSEDE V8.2.10 (STAMATAKIs 2014), also through the CIPRES Science Gateway, applying the GTR $+\mathrm{G}+\mathrm{I}$ model of nucleotide substitutions, with 1000 bootstrap iterations. Bootstrap values for the ML analysis were mapped on to the BI tree, the phylogeny figured in this publication. The full uncompressed tree is shown in supplemental materials (Fig. S1).

An alignment of 43 sequences of the 16S-23S ITS region for all currently known Oculatella species including our strains, was constructed in ClustalW, with constraints that forced alignment of all conserved domains (helices, Box-A, tRNA genes, etc.). From this alignment it was determined that a single ribosomal operon is present in Oculatella, as no multiple operons were recovered and all sequences possessed both tRNA genes. MP analysis was conducted using PAUP v. $4 \mathrm{~b} 10$. For this analysis, indels were counted as a fifth base and 10,000 bootstrap replicates were obtained. A BI analysis was also obtained from the 16S-23S ITS alignment, with coded indels ( 0 for gap, 1 for nucleotide). An unrooted phylogenetic tree was obtained with a BI analysis with 540,000 generations discarding the first $25 \%$ of samples as burn-in, choosing NST $=$ MIXED, and applying the GTR $+\mathrm{I}+\Gamma$ evolutionary model. This BI analysis had an estimated sample size (ESS) exceeding 380 for all parameters (average ESS ranging 476-1598), well above the average of 200 accepted as sufficient (DRUMMOND et al. 2006). Average standard deviation of split frequencies was $<0.005$ and the PSRF for this analysis was $=1.00$ for all parameters. For the ITS phylogeny, the BI topology is shown, with MP bootstrap values mapped on to the tree. All phylogenies in this paper were visualized in FigTree, and were subsequently edited in Adobe Illustrator (San Jose, CA).

The hypothetical secondary structures of conserved domains in the 16S-23S ITS region, including D1-D1', Box $\mathrm{B}, \mathrm{V} 2$, and V3 helices, were derived using $\mathrm{M}$-fold (ZuKeR 2003) and re-drawn in Adobe Illustrator. Differences from all described taxa from the two Mexican strains were indicated by using open and closed circles on variable nucleotides.

\section{RESULTS}

\section{Molecular evidence for taxonomic recognition}

The 16S rRNA phylogenetic analysis showed the five Synechococcales families recognized by MAI et al. (2018) to be monophyletic taxa, with well-supported nodes in most cases (Fig. 1). The Leptolyngbyaceae was exceptional in that this family had only marginal support (Fig. 1). An uncompressed version of this analysis is available in the supplemental materials (Fig. S1). The genus Oculatella was well-supported (1.00/99, BI posterior probabilities/ML bootstrap values). In this tree, Oculatella dilativaginata was sister to O. mojaviensis, while Oculatella leona was sister to but not well separated from $O$. atacamensis (Fig. 1). The phylogeny based on the $16 \mathrm{~S}-23 \mathrm{~S}$ ITS region gave better resolution for all species. In this analysis, $O$. leona was sister to $O$. mojaviensis, and $O$. dilatativagina was sister to the large clade containing $O$. atacamensis, O. ucrainica, O. coburnii, O. mojaviensis, and $O$. leona (Fig. 2). Every species for which multiple strains exist showed high bootstrap support for the species, and most nodes were well supported. We consider this phylogeny to be the superior analysis for examining evolutionary relationships among species.

Percent identities based upon the $16 \mathrm{~S}$ rRNA gene sequence data were high among species of Oculatella (Table S1). O. neakameniensis, O. kazantipica, O. hafneriensis, O. subterranea, O. cataractarum, and $O$. kauaiensis all had average percent identities with all species $<98.7 \%$, the threshold below which percent identity in prokaryotes serves as good evidence that the taxa are separate species (YARZA et al. 2014). The Western Hemisphere species from soils plus Oculatella ucrainica formed a group in which all species had average percent identities $>98.7 \%$. Consequently, other evidence must be obtained to recognize these as separate species.

Percent dissimilarity among $16 \mathrm{~S}-23 \mathrm{~S}$ ITS regions (Table 1) provided strong evidence that all species recognized in this paper belong to different species based upon criteria established by ERWIN \& THACKER (2008), which have been shown to be very effective in establishing species of cyanobacteria (OSORIO-SANTOS et al. 2014; PietrasiaK et al. 2014; BoHUNICKÁ et al. 2015; JohANSEN et al. 2017; SHALYGIN et al. 2017; VAZQueZ-Martínez et al. 2018; Mai et al. 2018; BeCERRA-AbSALón et al. 2018; GonZÁLEZ-RESENDIZ et al. 2018a, 2018b, 2019; PiETrasiak et al. 2019). All species in this comparison had percent dissimilarity $>3.0$ to all other species (Table 1), indicating evolutionary lineages worthy of taxonomic recognition (Osorio-SAntos et al. 2014; PIETRASIAK et al. 2019).

A final set of evidences for recognition of both $O$. dilatativagina and $O$. leona lies in the comparisons of ITS secondary structures. The D1-D1' helices were very similar in structure among all taxa, with the exception of $O$. kauaiensis, which has a much longer helix than the rest (Fig. 3). The most variable region of the helices was in the central stem portion of the helix. O. dilatativagina was quite dissimilar, with 12-19 nucleotide substitutions from all other species (excluding O. kauaiensis, which differed more). O. leona differed considerably less, with only 2-12 nucleotide substitutions (excluding O. kauaiensis) (Fig. 3). The V2 helices were highly similar among a number of the species: O. leona, O. dilatativagina, O. atacamensis, O. coburnii, O. mojaviensis, O. neakameniensis, and O. ucrainica (Fig. $4 \mathrm{~A}-\mathrm{F}, \mathrm{H}$ ). The other species were very distinct in their V2 helices (Fig. $4 \mathrm{G}$, I-L). The Box-B helices were likewise very similar in structure (Fig. $4 \mathrm{M}-\mathrm{V}$ ), with only $O$. subterranea differing in the loss of the basal opening due to a single substitution $(\mathrm{C} \rightarrow \mathrm{U})$ which then paired with A (Fig. $4 \mathrm{~W}$ ) and 


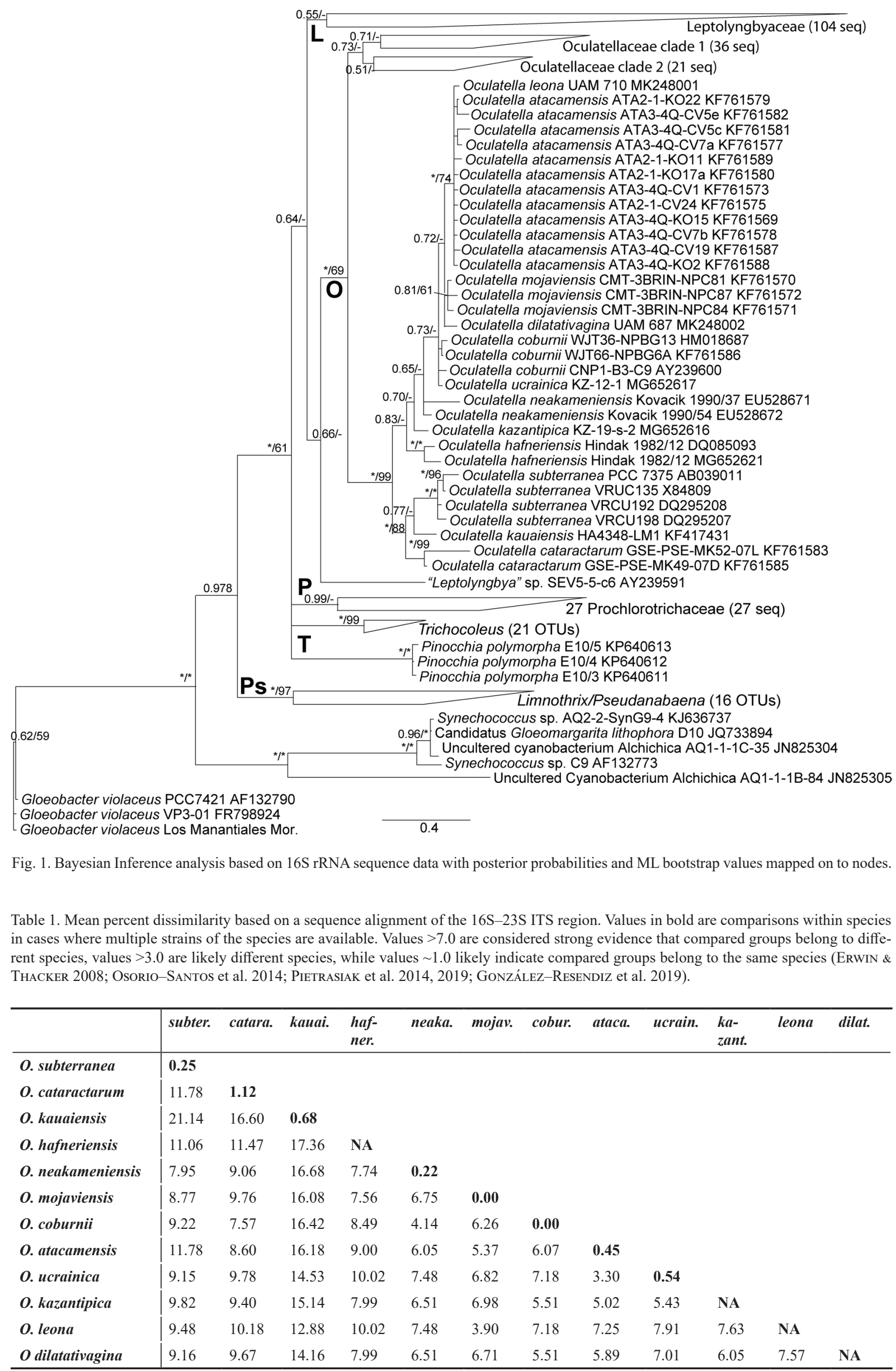




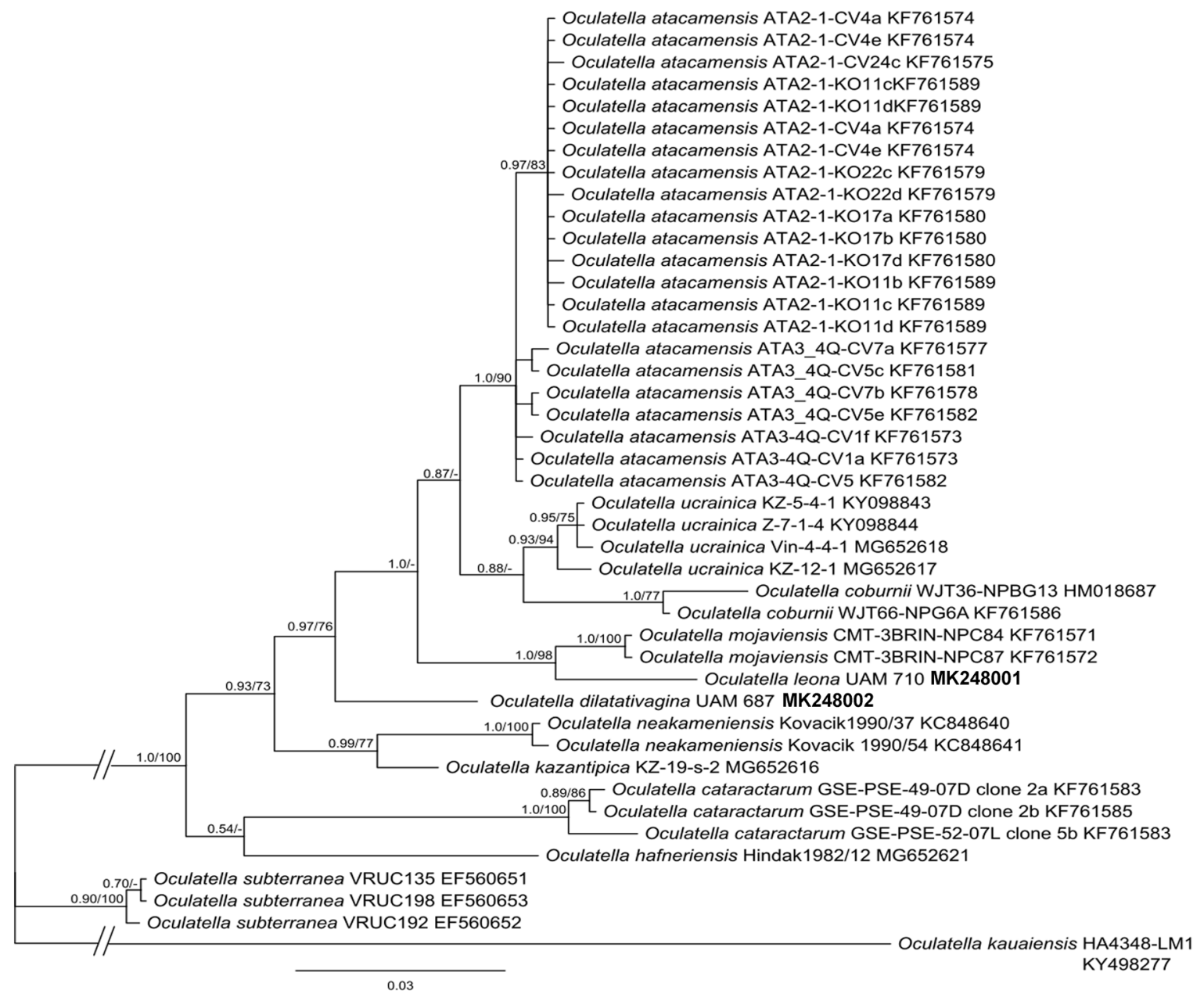

Fig. 2. Bayesian Inference analysis based on ITS alignment with posterior probabilities and MP bootstrap values mapped on to nodes.

O. kauaiensis losing two nucleotides in the terminal loop (Fig. 4 X). O. leona and O. dilatativagina Box-B helices differed in sequence from other taxa by only 0-7 nucleotide substitutions. Finally, the V3 helices showed differences in structure among some taxa, but many had the same structure $(O$. leona, $O$. dilatativaginata, O. coburnii, O. mojaviensis, O. hafneriensis, $O$. ucrainica, O. kazantipica; see Fig. 5). Considerable nucleotide substitutions were evident in most comparisons, although $O$. leona and $O$. mojaviensis had identical sequences in the V3 (Fig. 5 A, E).

\section{Morphological analysis}

$O$. dilatativagina had a very particular sheath. It was firm, generally wide, lamellate and with wavy edges, presenting the widest filaments of all the Oculatella species. O. cataractarum, O. kazantipica and $O$. ucranica also had widened sheaths, but these did not form wavy edges. On the other hand, $O$. dilatativagina's trichome was one of the thinnest, similar to $O$. neakameniensis, $O$. subterranea, $O$. hafneriensis and $O$. kazantipica (Table 2, Fig. 6, a-d).

$O$. leona and $O$. dilatativagina had isodiametric cells while the other Oculatella species were longer than wide (Table 2, Fig. 6, a-b and $\mathrm{f}-\mathrm{g}$ ).

Oculatella species morphologically did not have many differences. $O$. leona was very similar to $O$. mojaviensis, $O$. atacamensis, $O$. neakameniensis, especially in the sheath type, trichome color and absence of granules, but $O$. leona had slightly wider filaments (Table 2, Fig, 6, e-g).

\section{Descriptions of species \\ Oculatella dilatativagina I. Becerra-Absalón et} J.R.Johansen sp. nov. (Fig. 6 a-d, Table 2)

Diagnosis: Morphologically similar to $O$. kazantipica by the presence of widened, lamellate sheath, but $O$. dilatativagina differs in constrictions or very marked wavy edges in the sheath, also false branches were not observed, the cells are shorter, have no granules, and are from a different habitat. Ecologically similar to $O$. leona, O. mojaviensis, O. coburnii, O. atacamensis and O. neakameniensis, but morphologically differing from these species by the very widened sheath and by the maximum width of the filament.

Description: Thallus a thin mat, Filaments flexuous, lacking false branching, sometimes more than one trichome in a common sheath, $1.2-8 \mu \mathrm{m}$ wide. Sheath 


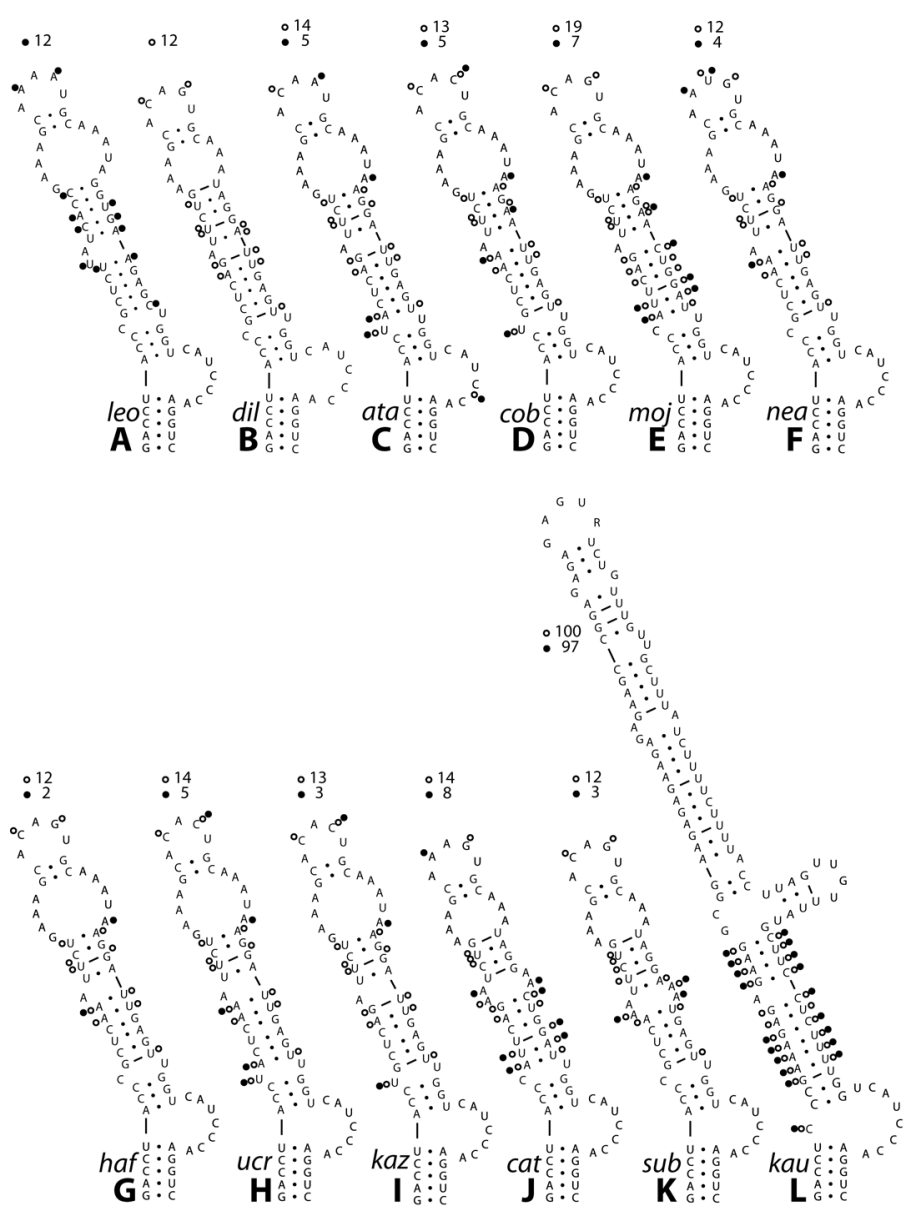

Fig. 3. Secondary structure of D1-D1' helix in all Oculatella species described to date, with nucleotides differing from $O$. leona due to substitutions, insertions, or deletions marked with open circles, and nucleotides similarly differing from $O$. dilatativagina marked with solid circles; summary numbers of nucleotide differences given above each helix. Due to extensive differences in the D1-D1' helix of O. kauaiensis, only the basal portion of the helix which has some similarity to the other helices is marked with circles. Abbreviations for each species are given to the left of each helix. (A) $O$. leona UAM 710; (B) O. dilatativagina UAM 687; (C) O. atacamensis ATA2-1-CV4; (D) O. coburnii WJT66-NPBG6A; (E) $O$. mojaviensis CNPC87; (F) O. neakammeniensis Kovacik 1990/37; (G) O. hafneriensis Hindak 1982/12; (H) $O$. ucrainica KZ-5-4-1; (I) O. kazantipica KZ-19-s-2; (J) O. cataractarum GSE-PSE49-07D; (K) O. subterranea VRUV135; (L) O. kauaiensis HA4348-LM1. Bold bases are substitutions, empty circles represent deletions, filled circles with refer to insertions firm, thin, colorless, becoming widened, lamellate, with wavy edges, up to $4 \mu \mathrm{m}$ wide. Trichomes not motile, constricted at the crosswalls, $1-1.8 \mu \mathrm{m}$ wide. Cells non-granular, blue-green, longer than wide, 2.1-4.4 $\mu \mathrm{m}$ long. Apical cells conically tapered when mature, with a prominent red granule at the tip of the cell, 4.4-5.0 $\mu \mathrm{m}$ long.

Habitat: Aerophytic, forming surface biocrust from semi-desert soils.

Type Locality: Ampliación La Peña, Mezquital Valley, Hidalgo, México, elevation 2010 m a.s.l., $20^{\circ} 16^{\prime} 02.9^{\prime \prime} \mathrm{N}$, 98 $54^{\prime} 57.5^{\prime \prime} \mathrm{W}$, collected 17 October 2014.

Holotype here designated: Collection number FCME CB18, Dried environmental soil sample deposited in Bio-crust collection of the Herbarium of Facultad de Ciencias, FCME, UNAM.

Isotype here designated: FCME CB18-ISO. Dried material of reference strain UAM 687 on glass fiber filter, Herbarium of Facultad de Ciencias, FCME, UNAM.

Isotype here designated: Reference strain UAM 687, cryopreserved in the Algal Culture Collection of the Universidad Autónoma de Madrid, Spain.

Reference Strain: UAM 687, Algal Culture Collection, Universidad Autónoma de Madrid, Spain.

Etymology: L.: dilatatus = widened, vagina (abl.) = with sheath; dilatativagina $=$ with widened sheath

Oculatella leona I. Becerra-Absalón et J.R.Johansen sp. nov. (Fig. 6 e-g, Table 2)

Diagnosis: Morphologically and ecologically similar to O. mojaviensis, O. atacamensis and O. coburnii, but differing by slightly thicker filaments and absence of false branching.

Description: Thallus a thin mat. Filaments flexuous, with a single trichome per sheath, lacking false branches, 2.9-4.4 $\mu \mathrm{m}$ wide. Sheath firm, thin, unlamellated, colorless. Trichomes not motile, not to slightly constricted at the crosswalls, 1.5-2.7 $\mu \mathrm{m}$ wide. Cells non-granular, blue-green, longer than wide, 2.4-4.4 $\mu \mathrm{m}$ long. Apical cells conically tapered when mature, with a prominent red granule at the tip of the cell, 4.0-4.9 $\mu \mathrm{m}$ long. Hormogonia observed, separated by simple fission without necridia.

Habitat:-Aerophytic, in biocrusts with other species from semi-desert soils.

Type Locality:- Outside of the cone of the volcanic lake, Atexcac, Puebla state, México, elevation 2046 m a.s.1., $19^{\circ} 20^{\prime} 13^{\prime \prime N}, 97^{\circ} 21^{\prime} 19^{\prime \prime} \mathrm{W}$, collected 8 March 2014.

Holotype here designated: Collection number FCME CB2, Dried environmental soil sample deposited in Bio-crust collection of the Herbarium of Facultad de 


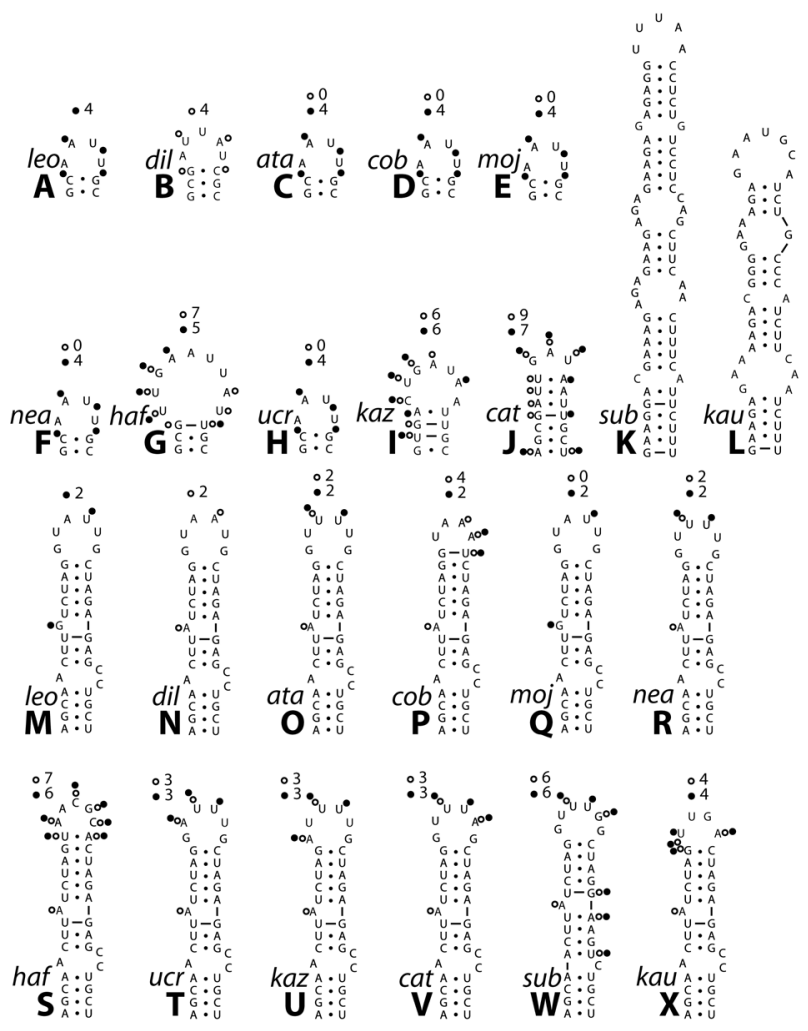

Fig. 4. Secondary structure of V2 helix (A-L) and Box-B helix $(\mathrm{M}-\mathrm{X})$ in all Oculatella species described to date, with nucleotides differing from $O$. leona due to substitutions, insertions, or deletions marked with open circles, and nucleotides similarly differing from O. dilatativagina marked with solid circles; summary numbers of nucleotide differences given above each helix. Due to extensive differences in the V2 helix of $O$. subterranea and $O$. kauaiensis these helices are not marked with circles. Abbreviations for each species are given to the left of each helix. (A) O. leona UAM 710; (B) O. dilatativagina UAM 687; (C) O. atacamensis ATA2-1-CV4; (D) O. coburnii WJT66-NPBG6A; (E) O. mojaviensis CNPC87; (F) O. neakammeniensis Kovacik 1990/37; (G) O. hafneriensis Hindak 1982/12; (H) O. ucrainica KZ-5-4-1; (I) O. kazantipica KZ-19-S-2; (J) O. cataractarum GSE-PSE49-07D; (K) O. subterranea VRUV135; (L) O. kauaiensis HA4348-LM1; (M) O. leona UAM 710; (N) O. dilatativagina UAM 687; (O) $O$. atacamensis ATA2-1-CV4; (P) O. coburnii WJT66-NPBG6A; (Q) O. mojaviensis CNPC87; (R) O. neakammeniensis Kovacik 1990/37; (S) O. hafneriensis Hindak 1982/12; (T) O. ucrainica KZ-5-4-1; (U) O. kazantipica KZ-19-s-2; (V) O. cataractarum GSE-PSE49-07D; (W) O. subterranea VRUV135; (X) O. kauaiensis HA4348-LM1.
Ciencias, FCME, UNAM.

Isotype here designated: FCME CB2-ISO. Dried material of reference strain UAM 710 on glass fiber filter, Herbarium of Facultad de Ciencias, FCME, UNAM.

Isotype here designated: Reference strain UAM 710, cryopreserved in the Algal Culture Collection of the Universidad Autónoma de Madrid, Spain.

Reference Strain: UAM 710, Algal Culture Collection, Universidad Autónoma de Madrid, Spain.

Etymology: leona, named in honor of our fellow cyanobacterial taxonomist, marine phycologist, and esteemed friend, Hilda León-Tejera.

\section{Discussion}

With this paper, Oculatella now has 12 named species. Given the clear morphological synapomorphy of the ability to produce a rhodopsin-like granule in the apical cells of filaments, it is likely that more cultures will be recognized as belonging to the genus and that they will receive the attention necessary to recognize at least some of them as new species. Oculatella is mostly confined to soils and subaerial habitats (ZAMmIT et al. 2012; Osorio-SAntos et al. 2014; Dulić et al. 2017; VinOGRADOva et al. 2017), although the discovery of $O$. hafneriensis from Hafnersee (Lake Hafner) in Austria and $O$. cataractarum from a waterfall in the Grand Staircase Escalante National Monument of Utah indicates that it is possible more aquatic or semi-aquatic species be discovered. For a genus that is only eight years old, it is especially diverse, and reflects the resolving power of $16 \mathrm{~S}-23 \mathrm{~S}$ ITS sequence data in recognizing and establishing lineages that represent evolutionary species.

The use of percent dissimilarity between all species of Oculatella described and our strains has been found to be fairly consistent criteria for the separation of cyanobacterial species. ERWIN \& THACKER (2008) originally separated 12 species of the unculturable Synechococcus spongiarum Usher, based on the observation that average between-species dissimilarity in the clade was $9.32 \%$, while the average within species dissimilarity was $0.83 \%$. However, the range of dissimilarities in individual interspecies comparisons was 3.66-21.22\%, while the range of dissimilarities in individual intraspecies comparisons was $0.16-2.58 \%$. They did not describe the species they identified, but their work was critical in showing the existence of evolutionary species within a genus cluster in which the species had percent identities based on 16S rRNA sequence data that were $>99 \%$. Osorio-Santos et al. 2014 found almost the same result in their comparisons of Oculatella species, with average interspecies dissimilarity $9.78 \%$ (range $4.14-21.36 \%$ ), and average intraspecies dissimilarity $0.47 \%$ (range $0-1.68 \%$ ). This study expands the interspecies dissimilarity range in the genus by a slight amount (3.30-21.36\%), while the intraspecies dissimilarity remains within the limits found in OsOrIo-SANTOS et al. (2014).

Since that time, several authors have used the 


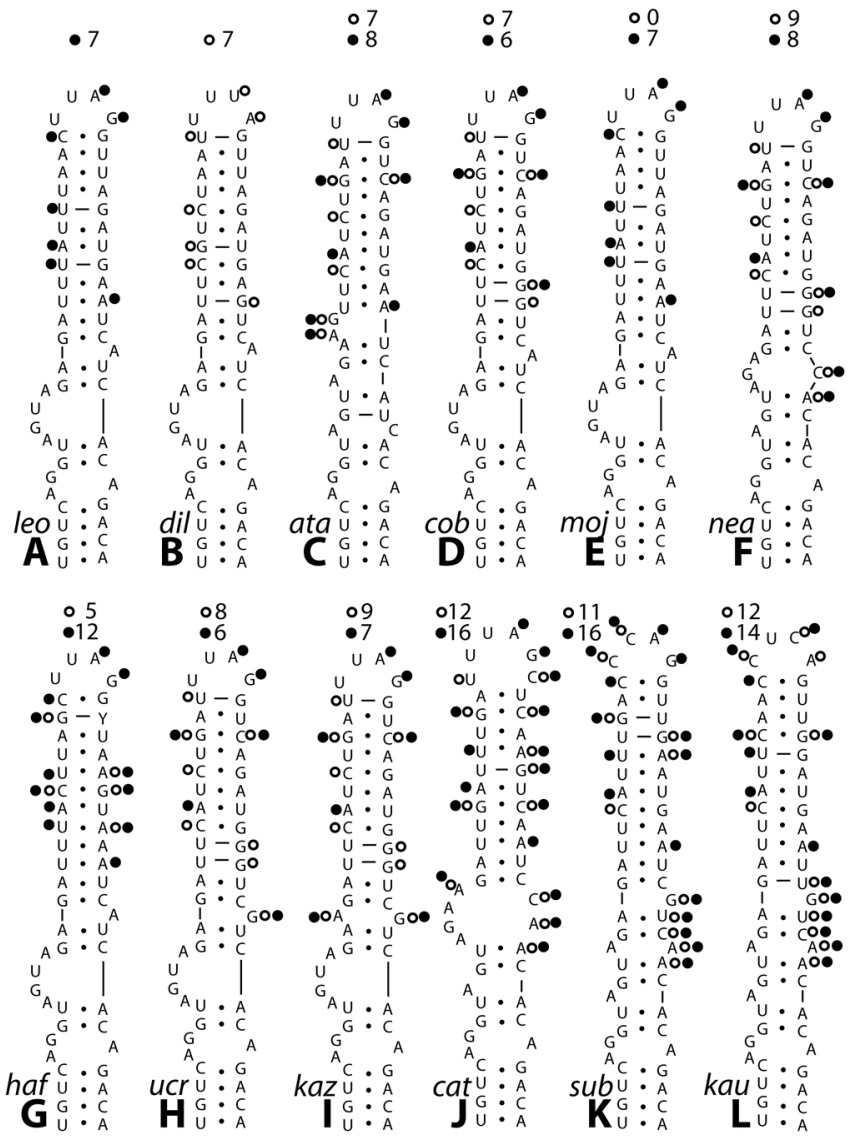

Fig. 5. Secondary structure of V3 helix in all Oculatella species described to date, with nucleotides differing from $O$. leona due to substitutions, insertions, or deletions marked with open circles, and nucleotides similarly differing from $O$. dilatativagina marked with solid circles; summary numbers of nucleotide differences given above each helix. Abbreviations for each species are given to the left of each helix. (A) O. leona UAM 710; (B) O. dilatativagina UAM 687; (C) O. atacamensis ATA2-1-CV4; (D) O. coburnii WJT66-NPBG6A; (E) O. mojaviensis CNPC87; (F) O. neakammeniensis Kovacik 1990/37; (G) O. hafneriensis Hindak 1982/12; (H) O. ucrainica KZ-5-4-1; (I) O. kazantipica KZ-19-S-2; (J) O. cataractarum GSE-PSE49-07D; (K) $O$. subterranea VRUV135; (L) O. kauaiensis HA4348-LM1. percent dissimilarity criterion to assist in defining species (PietrasiaK et al. 2014; BoHUnická et al. 2015; JoHANSEN et al. 2017; SHALYGIN et al. 2017; VAzQueZ-Martínez et al. 2018; Mai et al. 2018; BECERRA-ABSALÓn et al. 2018; GONZÁLEZ-RESENDIZ et al. 2018a, 2018b; MAREŠ et al. 2019; PIETRASIAK et al. 2019). These authors all found a clear discontinuity between interspecies dissimilarity and intraspecies dissimilarity consistent with both ERWIN \& THACKER (2008) and Osorio-SAnTos et al. (2014). Most stated that dissimilarities $>7 \%$ were strong evidence of lineage separation worthy of species recognition, while $<3 \%$ was likely good evidence for recognizing conspecific populations, with values falling between 3 and $7 \%$ being ambiguous. At this point, we would likely modify this criterion by contending that dissimilarity values $>3 \%$ are an indication of lineage separation worthy of taxonomic recognition, whereas dissimilarities $<2 \%$ represent conspecificity. Only a few species pairs have dissimilarities close to the cutoff of 3\%: Symplocastrum californicum (Drouet) Pietrasiak et J.R.Johans. and $S$. torsivum Pietrasiak et J.R.Johans. (PIETRASIAK et al. 2014), Oculatella leona and O. mojaviensis, and Desertifilum tharense Dadheech et Kriernitz and $D$. fontinale Dadheech, Mahmoud, Kotut et Kriernitz (GonZÁlez-REsEndiz et al. 2019). However, in these genera the intraspecies dissimilarity is $<1 \%$, indicating the discontinuity between interspecies and intraspecies dissimilarity remains clear.
Thus far, the thresholds established based upon percent dissimilarity of ITS regions in orthologous operons have been consistently useful for species recognition. Oculatella may prove to be the test case of this criterion given its widespread occurrence in arid soils. We anticipate that it will be recovered often in many regions of the world, and with enough sequenced strains, re-evaluation of the strength of this particular criterion may be necessary.

$O$. dilatativagina and $O$. leona occur in very similar habitats, biological soil crusts in tropical uplands of México. The two sites where they occur are less than $300 \mathrm{~km}$ apart, and one would expect desert soil organisms to be desiccation-resistant and capable of wind transport from one desert to another. However, these two species are not sister taxa, indicating that their close proximity does not mean that they share a recent common ancestor that does not include the other described species. This was also observed in Chroakolemma species isolated from the same sites (BECERRA-AbSALÓN et al. 2018). O. dilatativagina and $C$. opaca are both from the Mezquital Valley to the north, while $O$. leona and $C$. pellucida were found in the Atexac Valley to the south. The two valleys are separated by the Trans-Mexican Volcanic Belt, which began forming 20 million years ago. This mountain range appears to be an effective barrier to cyanobacterial dispersal, sufficient to allow radiation of prokaryotic lineages. The alternative explanation could be 

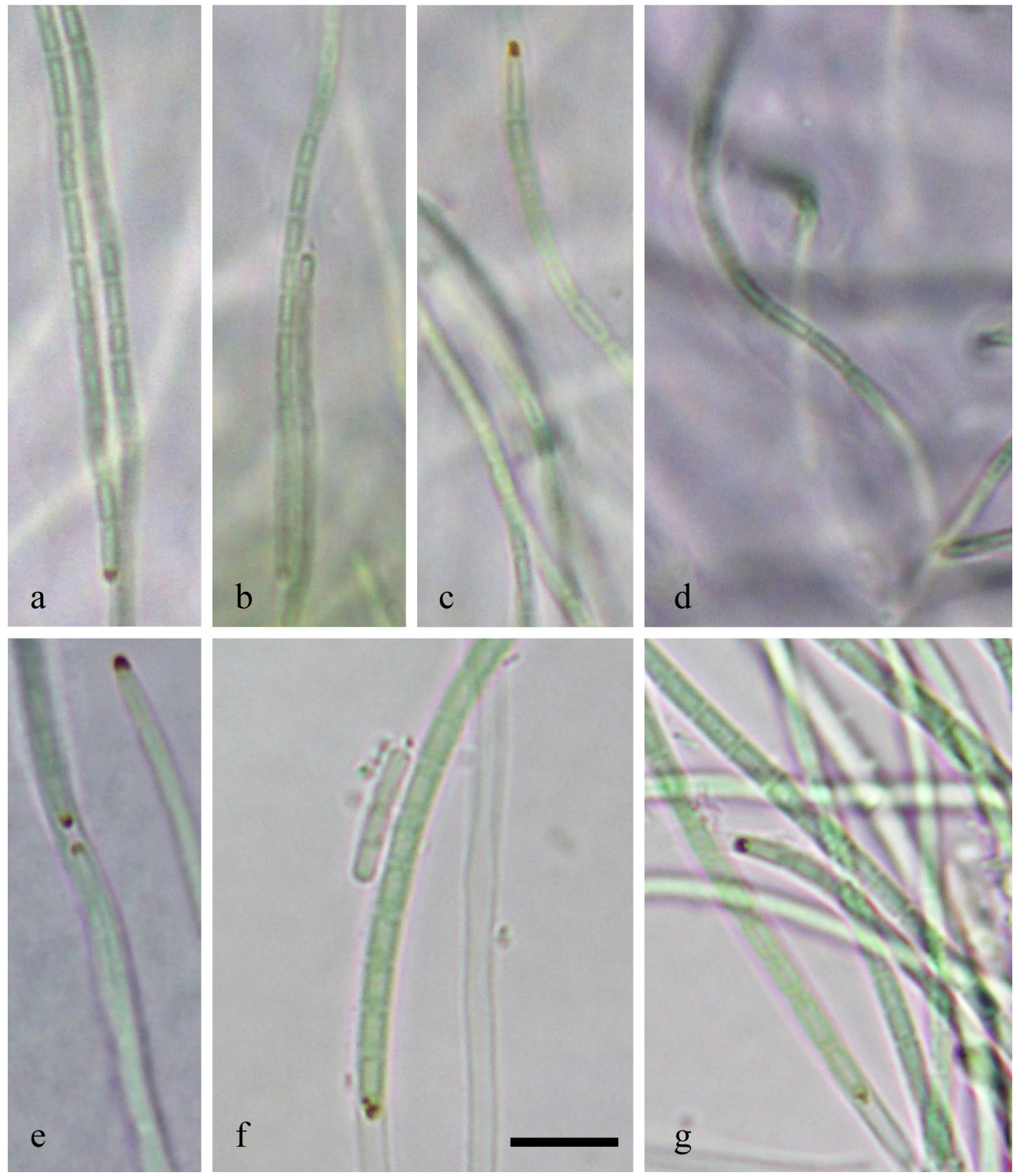

Fig. 6. Micrographs of Oculatella spp. in culture: (a-d) Oculatella dilatativagina, (a-b) Filaments with two trichomes by sheath, (c) rhodopsinlike reddish inclusion at the tip of mature apical cells, (d) widened, lamellate, wavy edges sheath; (e-g) Oculatella leona, (e) rhodopsin-like reddish inclusion at the tip of mature apical cells, (f) Sheath appearance and hormogonia, (g) filament appearance. Scale bar represents $8 \mu \mathrm{m}$.

that the range is not an effective barrier to dispersal, but rather the soils and climate are sufficiently different between the two sites that locally adapted populations (species) can maintain their lineage identity. Certainly, further study of the cyanobacteria in the soil crusts of these two regions is warranted.

\section{ACKNOWLEDGEMENTS}

This study was supported by grants from the Spanish Government and European Regional Funds (CGL2013-44870-R and
CGL2017-86258-R) and by a grant from the Universidad Autónoma de Madrid and Banco de Santander (CEAL-AL/2017-10). Thanks to Dra. Pilar Mateo and Dra. M. Angeles Muñoz Martín for the support offered to Dra. Itzel Becerra during her postdoctoral stay. Itzel Becerra-Absalón acknowledges support from Conacyt-Mexico postdoctoral Fellowship at Universidad Autónoma de Madrid. We thank Dirección de Asuntos del Personal Académico (DGAPA), from UNAM, for supporting PAPIIT Project AI204718. Finally thanks to Ricardo García Sandoval for technical assistance in image editing for the figures. 


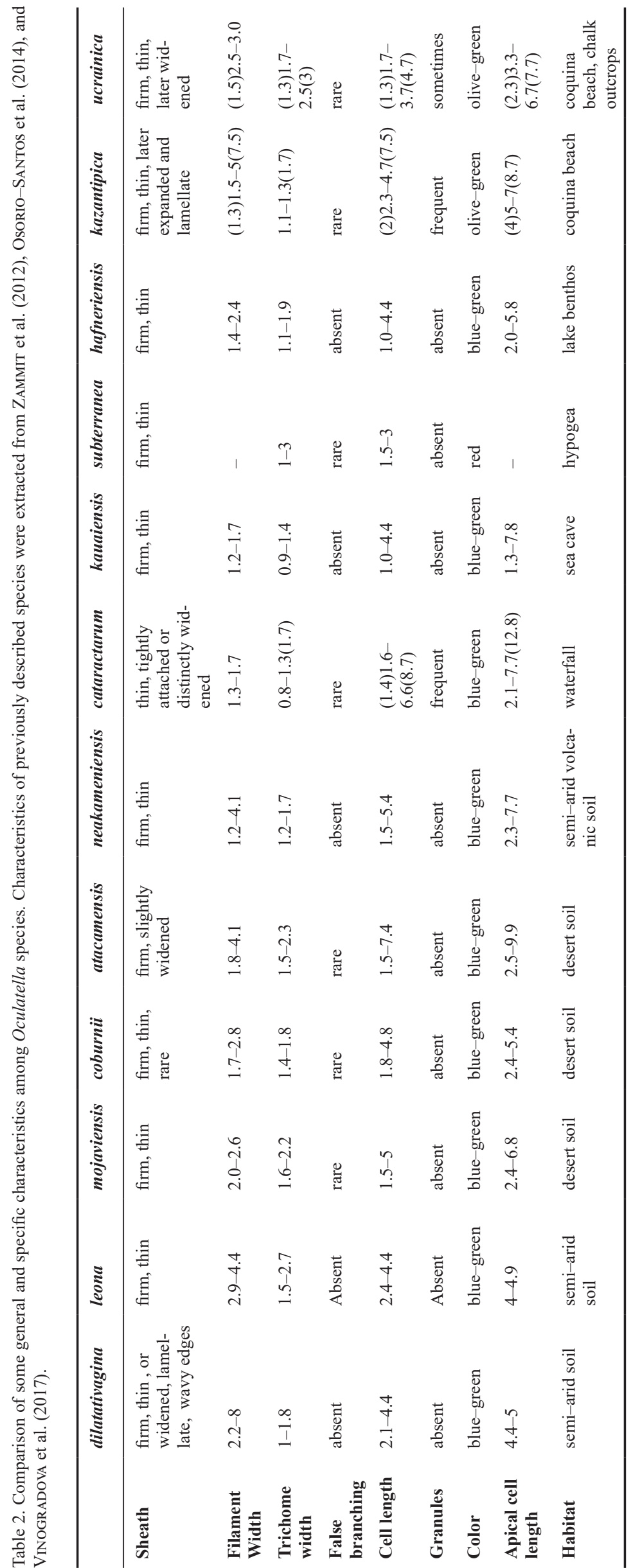

\section{REFERENCES}

Albertano, P., Barsanti, L., PASSARelli, v. \& GUALTIERI, P. (2000): A complex photoreceptive structure in the cyanobacterium Leptolyngbya sp. - Micron, 31: 27-34.

Allen, M. (1968): Simple conditions for growth of unicellular blue-green algae on plates. - J. Phycol. 4: 1-4.

BeCERRA-AbSAlón, I., JOHANSEN, J.R., Muñoz-Martín, M. \& Montejano, G. (2018): Chroakolemma gen. nov. (Leptolyngbyaceae, Cyanobacteria) from soil biocrusts in the semi-desert Central Region of Mexico. Phytotaxa 367: 201-218.

Bohunická, M., Pietrasiak, N., Johansen, J. R., Berrendero, E., Hauer, T., Gaysina, L.A., \& LuKeŠOvá, A. (2015): Roholtiella gen. nov. (Nostocales, Cyanobacteria) - a tapering and branching cyanobacteria of the family Nostocaceae. - Phytotaxa 197: 084-103.

Drummond, A.J., Ho, S.Y.W., Philips, M.J. \& Rambaut, A. (2006): Relaxed phylogenetics and dating with confidence. - PLoS Biology 4: e88.

Dulić, T., Meriluoto, J., Malešević, T.P., GajIĆ, V., Važıć, T., Tokodi, N., Obreht, I., Kostić, B., KosiJer, P., Khormali, F., Svirčev, Z. (2017): Cyanobacterial diversity and toxicity of biocrusts from the Caspian Lowland loess deposits, North Iran. Quat. Int. 429: 74-85

ERWIN, P.M. \& THACKeR, R.W. (2008): Cryptic diversity of the symbiotic cyanobacterium Synechococcus spongiarum among sponge hosts. - Molecular Ecology 17: 2937-2947.

Gelman, A. \& Rubin, D.B. (1992): Inference from iterative simulation using multiple sequences. - Statistical Science 7: 457-472.

Gkelis, S., Rajaniemi, P., Vardaka, E., Moustaka-Gouni, M. \& Lanaras, T. (2005): Limnothrix redekei (VAN GoOR) MEFFERT (Cyanobacteria) Strains from Lake Kastoria, Greece Form a Separate Phylogenetic Group. - Microbial Ecology 49: 176-182.

GonZÁLEZ-Reséndiz， L., JohANSEN, J., Alba-Lois, L., Segal-KischineVZKY, C., Escobar-Sánchez, V., Jimenez García, L.F., Hauer, T. \& LeÓNTejera, H. (2018a): Nunduva, a new marine genus of Rivulariaceae (Nostocales, Cyanobacteria) from marine rocky shores. - Fottea 18: 86-105.

GonZÁLEZ-ResÉndiz， L., JohANSEN, J., Escobar-Sánchez, V., SegalKischinevZKy, C., JimÉneZ-Gracía, F., Jimenez García, L.F. \& LeÓNTejera, H. (2018b): Two new species 
of Phyllonema (Rivulariaceae, Cyanobacteria) with an emendation of the genus. - J. Phycol. 54: 638-652.

GonzÁlez-Reséndiz, L., Johansen, J.R., LéON-Tejera, H., Sanchez, L., Segal-KischinevzKy, C., EscobarSÁncheZ, V \& Morales, M. (2019): A Bridge too far in naming species: a total evidence approach does not support recognition of four species in Desertifilum (cyanobacteria). - J. Phycol. 55: 898-911.

Johansen, J.R., Mareš, J., Pietrasiak, N., Bohunická, M., Zima, J., Štenclová, L. \& HaUer, T. (2017): Highly divergent 16S rRNA sequences in ribosomal operons of Scytonema hyalinum (Cyanobacteria). - PLoS ONE 12: $1-16$.

Lepére, C., Wilmotte, A. \& Meyer, B. (2000): Molecular diversity of Microcystis strains (Cyanophyceae, Chroococcales) based on 16S rDNA sequences. Syst. Geog. Pl. 70: 275-283.

KomÁReK, J. \& ANAGNostidis, K. (2005): Cyanoprokaryota: 2. - In BÜDel, B.; Gärtner, G.; Krienitz, L. \& SCHAGEL, M. (eds): Süßwasserflora von Mitteleuropa, Band 19/2.-759 pp. Elsevier Spektrum Akademischer Verlag, München.

Mai, T.; Johansen, J.R.; Pietrasiak, N.; Bohunická, M. \& Martin, M.P. (2018) Revision of the Synechococcales (Cyanobacteria) through recognition of four families including Oculatellaceae fam. nov. and Trichocoleaceae fam. nov. and six new genera containing 14 species. - Phytotaxa 365: 1-59.

Mareš, J.; Johansen, J.R.; Hauer, T.; Zima, J.JR.; Ventura, S.; Cuzman, O.; Tiribilli, B. \& KašTovskÝ, J. (2019): Taxonomic resolution of the genus Cyanothece (Chroococcales, Cyanobacteria), with a treatment on Gloeothece and three new genara Crocosphaera, Rippkaea, and Zehria. - J. Phycol. 55: 578-610.

Mateo, P.; Perona, E.; Berrendero, E.; Leganés, F.; Martín, M. \& Golubić, S. (2011): Life cycle as a stable trait in the evaluation of diversity of Nostoc from biofilms in rivers. - FEMS Microbiol. Ecol. 76:185-198.

Müller, J.; MÜLler, K.; NeInhuis, C. \& Quandt, D. (2010): PhyDE. - Available from: http://www.phyde.de/ (accessed 17 October 2019)

Osorio-Santos, K.; Pietrasiak, N.; Bohunická, M.; Miscoe, L.H.; KováčIK, L.; MarTin, M.P. \& Johansen J.R. (2014): Seven new species of Oculatella (Pseudanabaenales, Cyanobacteria): taxonomically recognizing cryptic diversification. - Eur. J. Phycol. 49: 450-470.

Pietrasiak, N.; MüHlsteinová, R.; Siegesmud, M.A. \& JoHANSEN, J.R. (2014): Phylogenetic placement of Symplocastrum (Phormidiaceae, Cyanophyceae) with a new combination $S$. californicum and two new species: S. flechtnerae and S. torsivum. - Phycologia 53: $529-541$

Pietrasiak, N.; Johansen, J.R.; Osorio-Santos, K.; Shaligyn, S. \& Martin, M.P. (2019): First insights into the population genetics of soil cyanobacteria with the description of a new genus: Myxacorys gen. nov. and two species from the Americas. - J. Phycol. 55: 976-996

Ronquist, F.; Teslenko, M.; VAn Der Mark, P.; Ayres, D.L.; Darling, A.; Hohna, S.; Larget, B.; LiU, L.; Suchard, M.A. \& Huelsenbeck, J.P. (2012): MrBayes 3.2: efficient bayesian phylogenetic inference and model choice across a large model space. - Syst. Biol. 61: 539-542.

Shalygin, S.; Shalygina, R.; Johansen, J.R.; Pietrasiak, N.;
Berrendero, E.; BohunickÁ, M.; Mareš, J. \& Sheil, C. (2017): Cyanomargarita gen. nov. (Nostocales, Cyanobacteria): convergent evolution resulting in a cryptic genus. - J. Phycol. 53: 762-777.

STAMATAKIs, A. (2014): RAxML version 8: a tool for phylogenetic analysis and post-analysis of large phylogenies. - Bioinformatics 30: 1312-1313.

Thompson, J.D.; Higgins, D.G. \& Gibson, T.J. (1994): Clustal $\mathrm{W}$ : improving the sensitivity of progressive multiple sequence alignment through sequence weighting, position-specific gap penalties and weight matrix choice. - Nucleic Acids Res 22: 4673-4680.

VÁzqueZ-Martínez, J.; GutierreZ-Villagomez, J.M.; FonesCa-García, C.; RamíreZ-Chávez, E.; Mondragón-SÁnchez, M.L.; PARTIDAMartínez, L.; Johansen, J.R. \& Molina-Torres, J. (2018) Nodosilinea chupicuarensis sp. nov. (Leptolyngbyaceae, Synechococcales) a subaerial cyanobacterium isolated from a stone monument in central Mexico. - Phytotaxa 334: 167-182.

Vinogradova, O.; Mikhailyuk, T.; Glaser, K.; Holzinger, A. \& KARSTEN, U. (2017): New species of Ocullatella (Synechococcales, Cyanobacteria) from terrestrial habitats of Ukraine. - Ukr. Bot. J. 74: 509-520.

Wilmotte, A.; Van der Auwera, G. \& De Wachter, R. (1993): Structure of the 16S ribosomal RNA of the thermophilic cyanobacterium Chlorogloeopsis HTF (Mastigocladus laminosus HTF) strain PCC7518 and phylogenetic analysis. - FEBS Letters 317: 96-100.

Yarza, P.; YilmaZ, P.; Pruesse, E.; GlöCKner, F.O.; LudWing, W.; SChleifer, K.H.; WhitMan, W.B.; EuzÉBY, J.; AMANN, R. \& Rosselló-MóRA, R. (2014): Uniting the classification of culture and uncultured bacteria and archea using 16S rRNA gene sequnces. Nat. Rev. Microbiol. 12: 635-645.

Zammit, G.; Billi, D. \& Albertano, P. (2012): The subaerophytic cyanobacterium Oculatella subterranea (Oscillatoriales, Cyanophyceae) gen. et sp. nov.: a cytomorphological and molecular description. - Eur. J. Phycol. 47: 341-354

Zuker, M. (2003): Mfold web server for nucleic acid folding and hybridization prediction. - Nucleic Acids Research 31: 3406-3415.

Supplementary material

The following supplementary material is available for this article:

Fig. S1. The 16S rRNA phylogenetic analysis showing the five Synechococcales families.

Table S1. Average percent identity based on 16S rRNA gene sequence data.

This material is available as part of the online article (http:// fottea.czechphycology.cz/contents)

(C) Czech Phycological Society (2020)

Received March 6, 2020

Accepted June 23, 2020 